\title{
THE INTERNAL FACTORS WHICH AFFECT THE INNOVATIVENESS OF TOURIST ENTERPRISES
}

\author{
Elżbieta Szymańska \\ Management Faculty, Bialystok University of Technology, \\ Wiejska str. 45A, 15-351 Biatystok, Poland \\ E-mail: e.szymanska@pb.edu.pl
}

\begin{abstract}
The aim of this article is to indicate internal factors which affect the enhancement of tourist enterprises innovativeness. The Author attempts to identify the main factors nased on the literature, subsequently verifying the theoretical assumptions in the empirical studies. There are present results of two conducted surveys: the survey performed on a group of 215 different tourist enterprises, and amoug them 98 travel agencies, and the survey performed on a group of 42 innovative touroperators. In order to achieve the objective, the questionnaire and rakk methods were used. The study showed the following - the owner play a major role but the importance of individual factors in innovative enterprises is much higher than in the average tourist enterprises.
\end{abstract}

Keywords: innovations, internal innovativeness factors, service sector, tourist business, enterprises, travel agencies, hotels.

JEL Classification: M20; O31.

\section{Introduction}

Having been ignored for a long time, innovation in services is now the object of surveys at the regional, national and international levels. Despite the fact that the share of the service sector in the economy of the Member States of the European Union significantly exceeds $50 \%$ of their GDP and is thus greater than that of industry, and mainly agriculture, the issues of innovativeness in this sector have not been sufficiently discerned in social-economic policy (Ustugi [Services] 2008: 3). Appreciable marginalisation of these issues is even more intense in the theoretical area and mainly occurs in economic sciences, as many contemporary economists have noted (Gallouj 2002; Rogoziński 2008; Gault 2010; Chang et al. 2012; Szymańska 2013). In the last decade, attempts to fill in the existing gap were undertaken, as evidenced by the research, to mention only the most significant studies, by the Eurostat, OECD and the University of Maastricht (UNU MERIT).

Researchers do not agree, either, on how innovation should be defined; therefore, different definitions can be found in the literature (cf. Szymańska 2013: 62-67). The Author adopts here the classical definition of innovation which was proposed in the early $20^{\text {th }}$ century by Joseph Schumpeter, called the father of innovation theory. According to him, innovation is (Schumpeter 1960: 4):
- the launch of the production of new products or the improvement of existing ones,

- the introduction of a new or improved production technology,

- the use of a new manner of sales or purchase,

- the opening of a new market,

- the use of new resources or intermediate products,

- the introduction of changes in the organisation of production.

The innovation thus understood mainly relates to production enterprises.

Since the research on service innovation is in statu nascendi and the lack of a comprehensive approach can be discerned the Author tries to fill in this gap. The research problem which the Author undertakes to address in this paper is the innovativeness of service enterprises and, in particular, the factors which drive it. The aim of this study is to indicate internal factors which affect the enhancement of corporate innovativeness, based on tourism enterprises.

The article is divided into two basic parts: the theoretical and the empirical. The first part consists of the considerations of the main factors of corporate innovativeness and ends with the presentation of a model which reflects the division of internal factors. The second part presents the results of two 
conducted surveys; specifically: the Author's survey performed on a group of 215 enterprises carried out in years 2006-2008 and the survey performed on a group of 42 innovative tour operators carried out in 2011-2012. The research covered tourism enterprises from all over Poland. Tourism services have been the fastest developing sector of the economies of the majority of industrialised countries over the last few decades in the area of services (Global tourism 2005: 7). This is the main reason why the Author has chosen tourism enterprises for her survey.

The article ends with conclusions from the research, recommendations for innovation strategy and an indication of subjects for a further discussion on these important issues. The study presents the original results with implications for both research and practice. A novelty in the scope of theory is the identification of the internal factors affecting the innovativeness of enterprises which provide tourism services. A novelty for economic practice is the possibility of applying the research results in innovation strategy of service enterprises.

\section{Conceptual background and literature review}

There are many descriptions of innovations in manufacturing companies in the literature (Aw et al. 2011; Ejdys, Krawczyk-Dembicka 2012) but relatively little on the innovation of service enterprises. Researchers note (Metcalfe, Miles 2012) that service enterprises can be innovative in their own right, even though the process of innovation and the kinds of innovation may be different from those traditionally associated with manufacturing and other primary activities (Gallouj 2002; Tether 2005). This difference ensues from three major reasons (Gallouj 2002: 15). Firstly, services are a process. Secondly, services are interactive. Thirdly, the service sector is one of extreme diversity. Moreover, in production enterprises innovativeness primarily depends on R\&D outlays and the application of modern technologies (Aw et al. 2011). Wide research on the factors affecting service enterprises was carried out by Gallouj and Savona (2009), Gault (2010), Urban (2014), Panfiluk (2015), and Szymańska (2009, 2013). The direction of the research was set out by the publications of the OECD and Eurostat, which appeared in the series called Frascati Family. The Oslo manual (2005) should be considered a milestone in research on service innovation.

In contrast to production enterprises, researchers consider the following exogenous factors affecting the innovativeness of service enterprises (innovation determinants) to be the most important: customer dialogue (Chesbrough 2010), clusters (Hollenstein 2003), innovation policy (Szymańska 2012), the membership in a network (Frenz, LettoGillies 2009), the cooperation with different institutions (Tether, Tajar 2008).

Anne-Mette Hjalager (1994) should be considered the precursor of research on innovation in the tourism industry. In her publications, the researcher addressed many important issues related to the innovation. She presented her research on the innovation patterns in sustainable tourism (1997), cultural tourism innovation systems (2009) and innovation in tourism in a welfare state perspective (2005). The OECD also explored innovation and growth drivers in tourism (Edited byWeiermair 2006) and laid down the foundations for the research on innovation in the economy. The comparability of the data collected, in accordance with the recommendations of the Oslo manual (2005: 25) that the surveys should be carried out on samples for which units should be selected in a random manner (Oslo 2005: 124); moreover, questionnaire survey and the interview method are suggested. Both methods were used in preparing the present publication.

It is recommended that the length of the period covered by observations related to innovation research should not be longer than three years and should not be shorter than a year (Oslo 2005: 136); therefore, the Author's survey covered a three-year period, in accordance with the definition that an innovative enterprise is such that has introduced at least one innovation in three years (Oslo 2005: 61).

A group of tourism enterprises doing business as tour operators and characterised by innovativeness was selected for a successive survey. The selection of these enterprises in Round II of the surveys was not random and it was based on the following premises:

- the need for the survey to address a selected group of economic operators, given the large heterogeneity of the sector;

- the dynamic development of the tourism sector in the last fifty years which was much faster than in the other sectors, as confirmed by the statistical data, which indicate that the number of travels from 1950 to 2012 grew by a factor of almost 40 , continues to grow and was over one billion (UNWTO 2013);

- the Author's good knowledge of the principles of the tourist market, especially operations of travel agencies, ensuing from the long-term management of her own travel agency (in 1991-2007), which makes it possible for her to avoid many inaccuracies 
and acquire a better understanding of the issues surveyed;

- the relatively poor exploration of innovation processes in the tourism sector; in particular, on the part of travel agencies, despite their large potential and significant role in economic growth.

Comprehensive research on the innovativeness of tourism enterprises was carried out for the first time in Poland (Szymańska 2009). This made it possible to indicate the following types of innovation: those related to the product, process, organization and technology. In addition, the contemporary literature also identified marketing innovation (Oslo manual 2005 and later, Szymańska 2013) and social innovation (Horizon 2020).

\section{Methods and the research procedure}

The research on the internal factors affecting the innovativeness of service enterprises was carried out in two rounds. The first round was performed in 2006-2008 and covered 215 enterprises, among which 3 layers were distinguished, i.e. travel agencies, hotels and passenger transport enterprises.

The second round of research, which was carried out in 2011-2012, was limited to most innovative tour operators (42 firms).

In Round I of the surveys, the respondents were able to repeatedly choose answers from among 4 internal variables. A binary scale (yes-no) was used in the questions contained in the survey questionnaire and during a telephone interview.

The survey on the basis of which the innovation process model was verified concerned the innovations introduced in 2009-2011. In its qualitative part, the survey was based on 42 in-depth interviews, to which, in the period from September 2011 to March 2012, requests by e-mail for their consent to participate in the survey and survey questionnaires were sent; alternatively, the questionnaires were handed out directly to the respondents. As a total, 62 survey questionnaires were collected from innovative firms with which an in-depth interview was carried out. The firms were selected for the survey on the basis of the following criteria:

- the implementation of a radical innovation, defined in the survey questionnaire as an innovation at the minimum national level, in a specific three-year period (2009-2011);

- the Author's verification of the reliability of information about the importance of an innovation through its analysis and comparison of information available on the websites of the tour operators active in Poland, in order to confirm the novel nature of an innovation on the minimum domestic market level;

- the respondent's indication of a positive financial result achieved due to a given innovation.

After verification, 42 tour operators which met all the above-mentioned criteria at the same time, were qualified for the survey. The purpose of the questionnaire used in the survey was to identify and evaluate internal variables which drove innovation at the enterprises surveyed. The choice options were arranged in an order of growing importance, patterned on a 5-point Likert scale, from 0 - nonexistent, 1 - unimportant, 2 - little importance, to 5 - of key significance for the implementation of innovations. The point of departure were 4 variables used in the Round I survey. They were set in a table in the form of a semi-open cafeteria, with the possibility of proposing additional variables.

There was a basic difference between the samples selected in the two rounds. The difference was that in the course of the Round I survey innovative firms were identified from among the respondents which participated in it. The sample was representative of the population of tourism enterprises in Poland. In turn, in Round II all the respondents were assessed as innovative firms and this was the condition for their participation in the survey. Round I of the surveys was indispensable to enable the implementation of Round II, since in its course the types of innovation occurring on the tourism market were identified (Szymańska 2009). In consequence, on the basis of the results obtained it was possible to compare the average service (tourist) firm with an innovative firm from the same sector. The order of the research investigations is shown in Figure 1.

It shows (Fig. 1) the successive stages of the research. On the basis of the relevant literature, in particular the Oslo manual (2005), a theoretical model was elaborated to present the exogenous factors affecting the competitiveness of service enterprises. The model was subsequently verified by empirical studies on selected service enterprises. The conclusions drawn in the course of the research are followed by a discussion on the results obtained.

The last stage shown in Figure 1 is the suggestion of the direction of the further research on the issue of innovativeness of service enterprises and the recommendations for innovation strategy in tourist companies. 


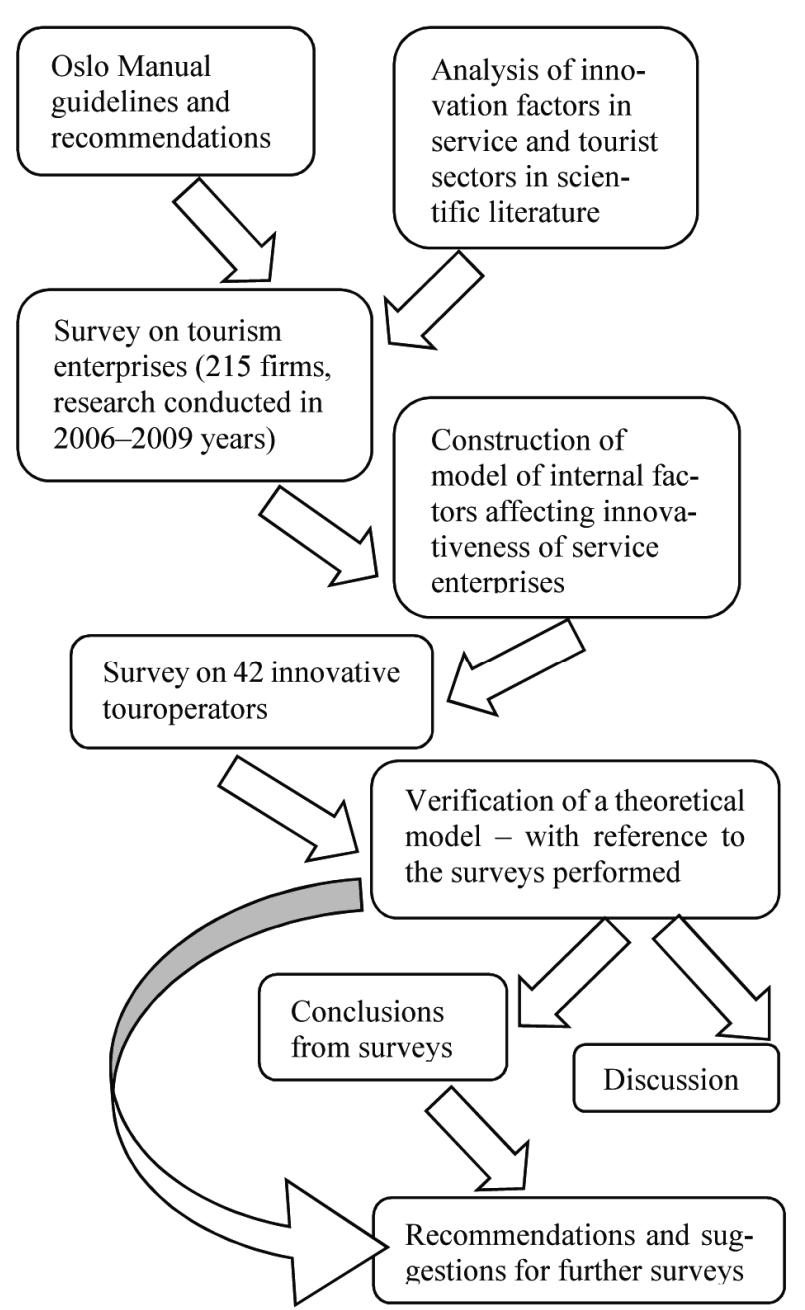

Fig. 1. The research procedure (Source: own elaborated)

\section{The internal factors affecting the innovativeness of enterprises - the construction of a theoretical background}

The point of departure for the construction of a model was the proposal for dividing the factors affecting the innovativeness of enterprises into two basic groups: the endogenous and those situated outside of enterprises, i.e. the co-called exogenous factors. In this study, the first ones were considered.

One can speak of many factors in the business environment of a company which influence the innovation process. According to Janasz and Koziol (2007), it consists of three planes: internal, the nearer one, i.e. the operational environment or the micro environment, and the farther one, i.e. the general environment or the macro environment. The construction of an economic model entails the need to use certain simplifications, which make it impossible to include in the model all the variables present in the economic reality (all the more so as a real, dynamic economic and political system is not fully cognisable); still, it does allow for the identification of the most important phenomena and processes (North 2005: 2).

In Round I, which is the basis for further research, the author diagnosed three internal factors of innovation, namely: the owners, employees and own research. On the basis of the conclusions obtained in this study (Szymańska 2009) a list of internal factors of innovation has been enlarged. According to Jasiński (1997: 38), the innovation propensity primarily depends on the nature of the general systemic solutions applied in the economy; therefore, the scheme includes innovation strategy. The propose model shown in Figure 2, omits external factors of innovation. It presents only factors inside the company.

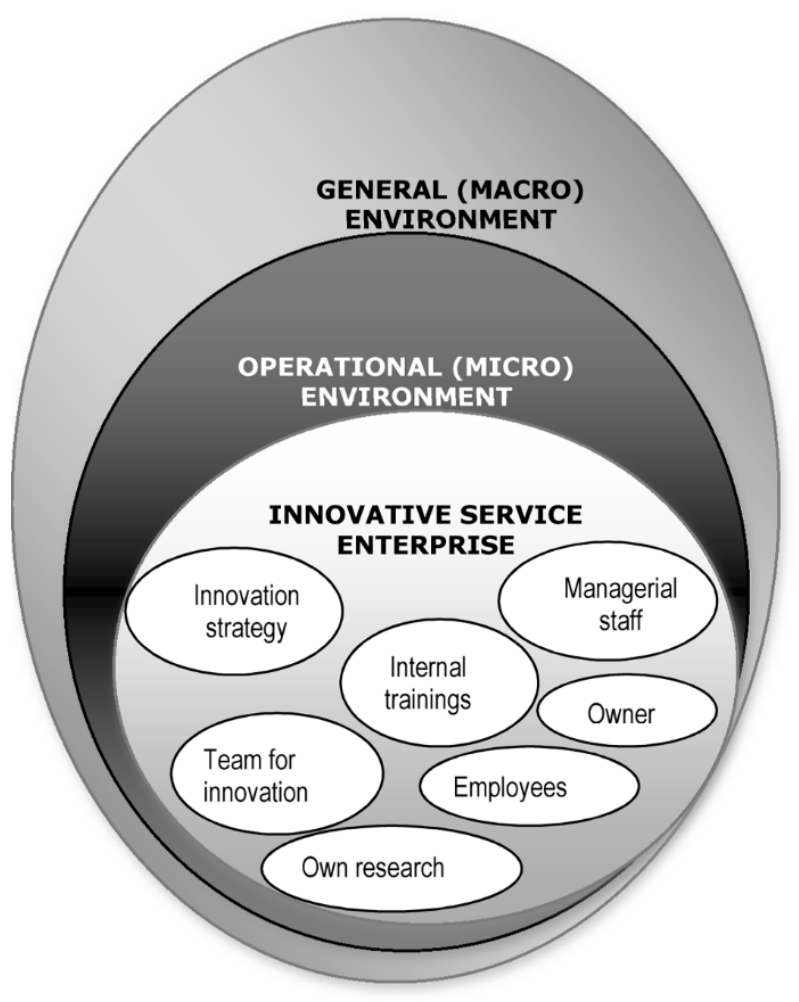

Fig. 2. The factors which affect the internal innovativeness of a enterprise (Source: Own elaboration based on Janasz and Kozioł (2007))

The scheme includes a total of 7 proposed factors placed in the innovative enterprise. In a group of internal factors of innovation service enterprises, belonging to human resources, are: employees, owner, managerial staff and team created especially for creation innovation. Other factors are: innovation strategy, trainings organized by firms themselves and their own research of market. The factors specified in the model will be examined in empirical studies on a sample of innovative companies operating in the tourism market - touroperators. 


\section{Research results}

The research done on two samples demonstrates substantial differences in the use of internal factors affecting the innovativeness of the enterprises surveyed. In previous studies, all three factors have similar importance for tourism. The results gained in Round I showed that the ideas of employees and owners, and also the results of the own research are important for innovation in every third examined company, with a slight predominance of the role of owner (Szymańska 2009). The table given below (Table 1) allows for these results to be compared, except for the innovation strategy, which will be discussed separately.

The table shows the mean of the ratings for each factor (Round II). The most important innovation is the creation of owner (average rating 4.5). On his large or crucial role indicated $74 \%$ of respondents, but $11 \%$ did not answer. Although the role of the manager staff looks like very important but in reality it is much smaller. As an important or crucial role of managers rated $38 \%$ of respondents and $21 \%$ did not answer. This is due to the fact that many respondents are micro-enterprises employing up to 9 people. The situation is similar in the case of market research. $33 \%$ of respondents does not conduct such studies, $7 \%$ did not answer and only $24 \%$ considered this factor as important or crucial for innovation. The ideas of employees have high or moderate importance in the innovation process $(60 \%)$ and the crucial role have only every tenth company, the same number (10\%) did not reply. Internal trainings and team of innovation does not play a significant role in the innovation process. The importance of training showed $21 \%$ of respondents and $66 \%$ did not answer. A special group for the innovation plays a big role in the $12 \%$ of respondents, while in $55 \%$ of companies it does not exist, $19 \%$ did not answers.

Strategy innovation plays an important role in the innovation process. Such a question were asked of all innovative enterprises in Round II. It turned out that more than half of the respondents $(55 \%)$ have a strategy for innovation. A much smaller number of respondents $(38 \%)$ has not such a strategy, and $7 \%$ did not answer.

The main results of the investigation are presented in Figure 3. There is visible in Figure 3 than the main factor in the innovation process is the owner. The result is common for innovative and rhe everage rourist enterprise. The main diference we can see on the picture is connected with the impact of each factor.

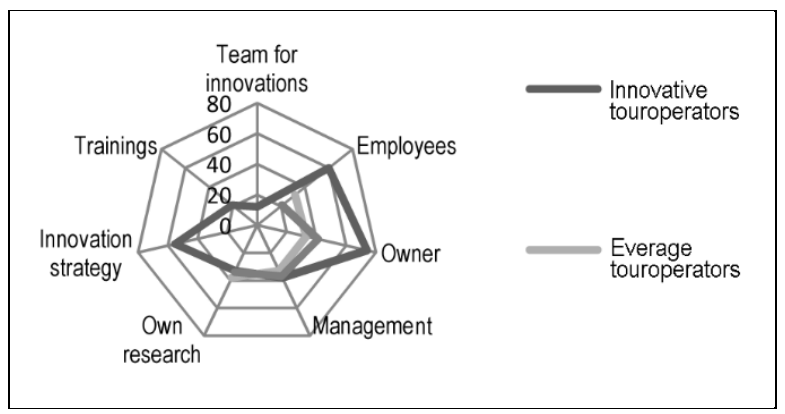

Fig. 3. The factors which affect the internal innovativeness of tourist enterprises (Source: own research and Szymańska 2009: 125-133; 2013: 217-221)

The research investigations performed should be discussed and lead to certain conclusions and recommendations.

Table 1. The internal factors affecting the innovativeness of tourist enterprises (Source: own research and Szymańska 2009: 125-133, 2013: 217-221)

\begin{tabular}{|c|c|c|c|c|c|c|}
\hline \multirow{2}{*}{ Indicators } & \multicolumn{4}{|c|}{$\begin{array}{l}\text { Innovative touriperators } \\
\text { Round II }\end{array}$} & \multirow{2}{*}{$\begin{array}{c}\text { Everage } \\
\text { touroperator } \\
\text { Round I } \\
\text { among } 98 \\
\text { entities in \% }\end{array}$} & \multirow{2}{*}{$\begin{array}{c}\text { Everage tour- } \\
\text { ist enterprise } \\
\text { Round I } \\
\text { among } 215 \\
\text { entities in \% }\end{array}$} \\
\hline & $\begin{array}{l}\text { Numer of } \\
\text { indications }\end{array}$ & $\begin{array}{l}\text { Number of } \\
\text { given points }\end{array}$ & $\begin{array}{c}\text { The everage } \\
\text { mark } \\
\text { (from } 1 \text { to } 5 \text { ) }\end{array}$ & $\begin{array}{c}\% \text { of } \\
\text { indications }\end{array}$ & & \\
\hline Team for innovations & 3 & 11 & 3,3 & $12 \%$ & & \\
\hline Employees & 9 & 31 & 3,4 & $60 \%$ & $32 \%$ & $21 \%$ \\
\hline Owner & 11 & 53 & 4,8 & $74 \%$ & $33 \%$ & $41 \%$ \\
\hline Management & 3 & 14 & 4,7 & $38 \%$ & $33 \%$ & $37 \%$ \\
\hline Own research & 8 & 32 & 4,0 & $33 \%$ & $38 \%$ & $34 \%$ \\
\hline Innovation strategy & 2 & 6 & 3,0 & $55 \%$ & & \\
\hline Trainings & 2 & 8 & 4,0 & $21 \%$ & & \\
\hline
\end{tabular}




\section{Discussion}

It should be noted that the problem of study of the factors of innovation in service companies is just at the beginning. We should consider why such a large role plays owners and other factors so small? The problem, which should be subject of further discussion is the low participation of employees in the innovation process. We may also note the low level of use of the different possibilities and sources of innovation in enterprises.

The main question is how to increase the activity of employees to associate them more in this process?

The problems suggested here should be subjected to further research. All the more so as that in the upcoming programming period in the European Union (2014-2020) a substantial part of financial resources can be designated for creating advisory networks. Before this happens it is well-advised to explore their impact on the innovativeness of service enterprises, including tourism enterprises.

The search for the causes of a low position of the service sector in innovation rankings, while it may perhaps ensue from inadequate research instruments. An enormous diversity (heterogeneity) of service enterprises makes comparisons difficult. Therefore, it would perhaps be well-advised to carry out research with their division into sub-sectors or perhaps it would be more appropriate to create universal instruments for measuring the innovativeness level at service enterprises. Similar conclusions were drawn in the documents containing guidance for the innovation policy of the European Union.

\section{Conclusions}

The results of the survey carried out made it possible to achieve the predetermined objective and to formulate the following conclusions regarding the internal factors affecting the innovativeness of service enterprises. In general, the present considerations regarding the variables inducing radical innovation processes at tour operators confirmed the results of the previous survey on the innovativeness of tourism enterprises. In the first study (20062009) were proposed three factors of internal innovation. While further research (Round II, 20102012) extended this list to 7 factors.

Detailed conclusions are presented below:

- comparing the results of both rounds should be noted that for the average tourist enterprise, each of the three factors (the owner, employees and market research) played a similar role and was valid for about $33 \%$ of the respondents. However, in the research group of innovative companies (Round II) the owner of the company definitely plays a major role (average rating 4.5), because $74 \%$ respondents pointed out their role as most important o crucial;

- other internal factors play a much smaller role in the innovation process;

- the ideas of employees have high or moderate importance in the innovation process for $60 \%$ respondents, and the crucial role have only every tenth company;

- managers plays an important role in $38 \%$ innovative tour operator;

- in the case of market research $24 \%$ of respondents conduct such studies;

- internal trainings and team of innovation does not play a significant role in the innovation process;

- $55 \%$ respondents have a strategy for innovation.

The identification and evaluation of the importance of the internal factors affecting the innovativeness of tourism service enterprises which are the leading ones in this respect make a contribution to innovation theory, which is part of economic sciences. A contribution to economic practice is the possibility of applying the research results in innovation planning and strategy construction.

\section{Recommendations for further research and practice}

In addition to the conclusions regarding the factors affecting the innovativeness of service enterprises, the following recommendations can also be formulated concerning the research methodology. There is a clear shortage of research on the factors affecting the innovativeness of service enterprises on which, after all, the Polish and European economies depend. In many publications (OECD, Eurostat), it has been demonstrated that the innovation level depends on the R\&D outlays. On the other hand, however, the national innovation policy - which certainly encompasses these outlays - shapes the market conditions in a given country.

It seems, therefore, that the innovation strategy of service company should focus, on the one hand, on facilitating cooperation and an exchange of information among the individual actors in the innovation process and, on the other hand, on reducing and eliminating restrictions impeding this cooperation. Accordingly, certain recommendations can be specified for corporate strategy contributing to the 
innovativeness of the service sector. Namely, action should be taken to:

- specify the principles of an effective innovation strategy, since the results of the surveys in Round II demonstrated that it should include mobilization (higher activity) of employs in the innovation process;

- ensure a more effective science policy and opportunities for extending and strengthening cooperation between science and business, for example, including researchers in the preparation of a strategy or market research;

- the foresight methodology seems to be the optimum tool for designing innovation; it would involve internal actors of company, local governments, customers and tourismrelated non-governmental organisations in the process of designing innovation. Practical implementation guidance for the Polish conditions can be found in the references (Ejdys, Krawczyk-Dembicka 2012) and on the website of the Ministry of Science and Higher Education;

- adjust the instruments for measuring innovativeness to the specificity of the service sector.

Given the still unsolved problem of the insufficient innovativeness of the Polish economy and the European economy as a whole, the identification of the specificity of the innovation processes unfolding in the service sector and the improvement of the innovation management in the contemporary economy require modernisation of research instruments and a deeper exploration of these issues. Conclusions and recommendations should contribute to the development of innovation theory and be applied in the economic practice of not only tourism enterprises, but also other service enterprises.

\section{Disclosure statement}

I don't have any competing financial, professional, or personal interests from other parties.

\section{References}

Aw, B. Y.; Roberts, V.; Xu, D. Y. 2011. R\&D investment, exporting, and productivity dynamics, American Economic Review 101(4): 1312-1344. http://dx.doi.org/10.1257/aer.101.4.1312

Chang, Y.-Ch.; Linton, J. D.; Chen, M.-N. 2012. Service regime: an empirical analysis of innovation patterns in service firms, Technological Forecasting \& Social Change 79: 1569-1582.

http://dx.doi.org/10.1016/j.techfore.2012.05.017
Chesbrough, H. W. 2010. Business model innovation: opportunities and barriers, Long Range Planning 43: 354-363.

http://dx.doi.org/10.1016/j.lrp.2009.07.010

Ejdys, J.; Krawczyk-Dembicka, E. 2012. Priority technologies and research directions in Polish foresight activities, Problemy Eksploatacji [Problems of Exploitation] 4: 117-127.

Frenz, M.; Letto-Gillies, G. 2009. The impact on innovation performance of different sources of knowledge: evidence from the UK Community Innovation Survey, Research Policy 38(7): 1125-1135. http://dx.doi.org/10.1016/j.respol.2009.05.002

Gallouj F. 2002. Innovation in the service economy. The New wealth of nations. UK\&USA, Northampton: Edward Elgar.

Gallouj, F.; Savona, M. 2009. Innovation in services: the review of the debate and a research agenda, Journal of Evolutionary Economics 19 (2): 149-172. http://dx.doi.org/10.1007/s00191-008-0126-4

Gault, F. 2010.-Innovation strategies for a global economy. Cheltenham, UK: Edward Elgar. http://dx.doi.org/10.4337/9781849806725

Global tourism. 2005. W. F. Theobald (Ed.). Elsevier Ltd, London.

Hjalager, A.-M. 1994. Dynamic innovation in the tourism industry, Progress in Tourism and Hospitality Management 6: 197-224.

Hjalager, A.-M. 1997. Innovation patterns in sustainable tourism - an analytical typology, Tourism Management 18(1): 35-41. http://dx.doi.org/10.1016/S0261-5177(96)00096-9

Hjalager, A.-M. 2005. Innovation in tourism in a welfare state perspective, Scandinavian Journal of Hospitality and Tourism 5(1): 46-54. http://dx.doi.org/10.1080/15022250510014282

Hjalager, A.-M. 2009. Cultural tourism innovation systems - the Roskilde festival, Scandinavian Journal of Hospitality and Tourism 9(2/3): 266-287. http://dx.doi.org/10.1080/15022250903034406

Hollenstein, H. 2003. Innovation modes in the Swiss service sector: a cluster analysis based on firm-level data, Research Policy 32: 845-863. http://dx.doi.org/10.1016/S0048-7333(02)00091-4

Horizon 2020. 2016. [Online], [cited 29 February 2016]. Available from Internet: https://ec.europa.eu/programmes/horizon2020/

Janasz, W.; Kozioł, K. 2007. Determinanty działalności innowacyjnej przedsiębiorstw [The determinants of the corporate innovation activity]. Warsaw: PWE.

Jasiński, A. H. 1997. Innowacje i polityka innowacyjna [Innovations and innovation policy]. Białystok: Publishing House of the University of Bialystok.

Metcalfe, J. S.; Miles I. 2012. Innovation systems in the service economy: Measurement and case study analysis. UK: Springer. 
North, D. C. 2005. Understanding the process of economic change. Princeton, Oxford: Princeton University Press.

Oslo manual. 2005. 3rd ed. OECD/European Communities/Eurostat.

Panfiluk, E. 2015. Impact of a tourist event of a regional range on the development of tourism, Social and Behavioral Sciences 213: 1020-1027.

Rogoziński, K. 2008. Zarys nowego paradygmatu teorii usług [An outline of a new paradigm in the theory of services], in Ustugi w Polsce - nauka, dydaktyka i praktyka wobec wyzwań przyszłości [Services in Poland-science, teaching and practice in the face of challenges of the future], vol. I: Scientific Journals of the University of Szczecin. Economic Problems of Services. 497.

Schumpeter, J. 1960, The theory of economic development, galaxy book, New York 1932. The Polish edition: Teoria rozwoju gospodarczego. Warsaw PWN.

Szymańska, E. 2009. Innowacyjność przedsiębiorstw turystycznych $w$ Polsce [Innovativeness of tourism enterprises in Poland]. Białystok: Publishing House of the Bialystok University of Technology.

Szymańska, E. 2012. Polityka proinnowacyjna $w$ Polsce [Pro-innovation policy in Poland], in K. Meredyk, A. Wildowicz-Giegiel (Eds.). Przestanki konsolidacji sektora $B+R$ [The Drivers of Consolidation of the R\&D Sector]. Białystok: Publishing House of the Bialystok University of Technology.
Szymańska, E. 2013, Procesy innowacyjne przedsięborstw świadczacych ustugi $w$ zakresie organizacji imprez turystycznych [The innovation processes in enterprises which render services in the scope of the organisation of tourism events]. Bialystok: Publishing House of the Bialystok University of Technology.

Tether, B. S.; Tajar, A. 2008. Beyond industry - university links: sourcing knowledge for innovation from consultants, private research organizations and the public science-base, Research Policy 37: 10791095. http://dx.doi.org/10.1016/j.respol.2008.04.003

Tether, B. S. 2005. Do services innovate (differently)? Insights from the European Innobarometer Survey, Industry and Innovation 12(2): 153-184. http://dx.doi.org/10.1080/13662710500087891

UNWTO World Tourism Barometer. 2013. [Online], [cited 15 March 2015]. Available from Internet: http://mkt.unwto.org/en/barometer

Usługi w Polsce - nauka, dydaktyka i praktyka wobec wyzwań przyszłości [Services in Poland - science, teaching and practice in the face of challenges of the future]. 2008. Economic Problems of Services 20(497): 3-12.

Urban, W. 2014 Service design for co-produced service excellence, Social Sciences 4: 26-33.

Weiermair, K. (Ed.). 2006. Product improvement or innovation: what is the key to success in tourism?, in Innovation and growth in tourism. Paris: OECD, 53-69. http://dx.doi.org/10.1787/9789264025028-5en 